\title{
First record of Poekilloptera phalaenoides found on Tachigali vulgaris (Fabaceae: Caesalpinioideae) in southwestern of Goiás, Brazil
}

\author{
Carlos de Melo e Silva-Neto ${ }^{a^{*}}$, José Neiva Mesquita-Neto ${ }^{b}$ Bruno Bastos Gonçalvesc, Lucas Marques de \\ Camargos $^{\mathrm{d}}$ \\ a Instituto Federal de Educação, Ciência e Tecnologia de Goiás, Goiás, 766000-000, Brasil. *carloskoa@gmail.com \\ ${ }^{b}$ Instituto de Ciências Biológicas, Departamento de Botânica, Universidade Federal de Minas Gerais, Belo Horizonte, 31270-901, Brasil. \\ ${ }^{c}$ Laboratório de Comportamento Celular, Instituto de Ciências Biológica, Universidade Federal de Goiás, Goiás, 74001970, Brasil. \\ ${ }^{d}$ University of Minnesota, Department of Entomology, Saint. Paul, Minnesota, 55108, Estados Unidos.
}

Recebido: 25 julho 2017 / Aceito: 8 setembro 2017 / Publicado online: 27 setembro 2017

\begin{abstract}
The leafhopper Poekilloptera phalaenoides L. (Auchenorrhyncha: Flatidae) is a very important species in agriculture because it causes damages and economic losses in agricultural activities. In observing fragments of semi-deciduous forest, riparian forest and cerrado forest (Cerradão) in Jataí, Montividiu and Paraúna in the southwest of the state of Goiás during the month of January 2012, were observed natural populations of Tachigali vulgaris (carvoeiro-branco). In the southwest of Goiás, an important agricultural region of the country, little is known about the damage caused to commercial crops by the leafhopper treated in this work, but here we call attention to the action of an agricultural pest interacting negatively with the native vegetation. The presence of $P$. phalaenoides in the Cerrado is already known, but the presence of the spittlebug in the southwest of the state of Goiás in T. vulgaris, especially in a situation of damage to the native population of the tree in forest fragments surrounded by agricultural crops. Thus, the objective of this work is to bring this first record of $P$. phalaenoides in $T$. vulgaris in the Cerrado of southwestern goiano.
\end{abstract}

Keywords: leafhopper, Cerrado, phytophagous, honeydew, host

\section{Primeiro registro de Poekilloptera phalaenoides encontrados em Tachigali vulgaris (Fabaceae: Caesalpinioideae) no sudoeste de Goiás, Brasil}

\begin{abstract}
Resumo
A cigarrinha Poekilloptera phalaenoides L. (Auchenorrhyncha: Flatidae) é uma conhecida espécie dentre culturas agrícolas e de interesse econômico devido os danos causados em atividades agrícolas. Observando fragmentos de mata estacional semidecidual, mata ciliar e cerradão em Jataí, Montividiu e Paraúna no sudoeste do estado de Goiás, durante o mês de janeiro de 2012, foram observadas populações naturais de Tachigali vulgaris (carvoeiro-branco). Em áreas que P. phalaenoides reduz o fitness de T. vulgaris, o ritmo da sucessão ecológica da área poderá ser modificado dependendo dos níveis da infestação das plantas. A presença de $P$. phalaenoides no Cerrado já é conhecida, mas a presença da cigarrinha no sudoeste do Estado de Goiás em T. vulgaris, especialmente em situação de prejuízo a população nativa em fragmentos florestais cercados de culturas agrícolas, é relato científico que torna importante este trabalho. Assim o objetivo deste trabalho é trazer este primeiro registro de $P$. phalaenoides em T. vulgaris no Cerrado do sudoeste goiano.
\end{abstract}

Palavras-chave: Cigarrinha, Cerrado, fitófago, honeydew, hospedeiro

\section{Introduction}

P. phalaenoides Linnaeus, 1758 (Auchenorrhyncha: Flatidae) is a very important species in agriculture, because it is a common prague of Cassia, Delonix (Caesalpiniaceae), Cajanus, Dipterix (Fabaceae), Manguifera (Anacardiaceae), Annona (Annonaceae), Eucalyptus, Psidium (Myrtaceae), Rosa, Prunus (Rosaceae), Coffea (Rubiaceae), Citrus (Rutaceae), Theobroma (Malvaceae), Enterolobium, Pithecelobium, Inga, Albizia, Acacia (A. mangium) e Mimosa caesalpinieaefolia (Mimosaceae) (Maes 2004; Querino et al., 2007; Guimarães de Menezes et al, 2012). This species causes big damage, resulting in economic losses (Del-Claro e Oliveira, 1999; Fischer et al., 2005; Styrsky e Eubanks, 2007).

$P$. phalaenoidesis a phytophagous leafhopper and when it is feeding of the host plant, the leafhopper produces the honeydew (a very concentrate sugar), allowing that it continues to absorb more nectar. This honeydew is a stick substance that glues on leaves, branches and even on the ground (Maes, 2004). Querino et al., 2007 suggests that this 
substance obstructs the breath, transpiration and photosynthesis process and, probably reducing the vegetative growth, fructification and, consequently, the success of the reproduction process of the plant host (Del-Claro e Oliveira, 1999; Fischer et al., 2005; Styrsky e Eubanks, 2007; Melo et al, 2016).

The presence of $P$. phalaenoides in the Cerrado is already known (Oliveira e Frizzas, 2015), however, the presence of the spittlebug in the southwest of the state of Goiás in $T$. vulgaris, especially in a situation of damage to the native population of the tree in forest fragments surrounded by agricultural crops, was not registered. Thus, the objective of this work is to present the first record of $P$. phalaenoides in $T$. vulgaris in the Cerrado of southwestern Goiania.

The points were tagged in remnants of the Cerrado phytophysiognomy using the geographical coordinates of the Garmin e-trex GPS. So, in an observation of s Semideciduous Forest, Riparian Forest and Cerradão fragments, at Jataí (n = $5 ; 17^{\circ} 42^{\prime} \mathrm{S}$ and $\left.51^{\circ} 30^{\prime} \mathrm{W}\right)$, Montividiu $\left(\mathrm{n}=10 ; 17^{\circ} 05^{\prime} \mathrm{S}\right.$ and $\left.50^{\circ} 40^{\prime} \mathrm{W}\right)$ and Paraúna $\left(\mathrm{n}=10 ; 17^{\circ} 30^{\prime} \mathrm{S}\right.$ and $\left.51^{\circ} 18^{\prime} \mathrm{W}\right)$, southwest of Goiás, Brazil in 2012, January. For the survey and identification of the botanical species in the marked points, plots of 20x30 $\mathrm{m}^{2}$ were marked in each locality. T. vulgaris $\mathrm{L}$. G. Silva and H. C. Lima (Fabaceae: Caesalpinioideae) were identified with the help of a botanical identification key (Barroso et al., 1991).

In order to identify the sucking insects, active sampling through the use of entomological net and deadly camera was performed (Silva-Neto et al., 2016). Flat stereomicroscope with a camera lucida attached and photographic cameras were used. In order to identify the species, the entomofauna identification keys (Baptista, 2006; Fujihara et al., 2011) and entomological collections of the Federal University of Goiás were used as reference (Entomological collection of the Laboratory of Plant Reproductive Biology).

Here, we showed the first record of $P$. phalaenoides found on T. vulgaris L. G. Silva \& H. C. Lima (Fabaceae: Caesalpinioideae) in south-West of Goiás, Brazil. The presence of this leafhopper in species with economic interest is very known, but few observations have been made about native species in natural areas. Natural populations of $T$. vulgaris was observed and all of them presented the leafhopper $P$. phalaenoides.

We observe many individuals of T. vulgaris damaged and its branches were senescent when the leafhoppers were there (Figure 1). We also found, above the T. vulgaris, leafhopper individuals in a large number (ten or more), in both stages, mature and immature stage. Were also observed populations of ants feeding the honeydew, near the nectar, like they were protecting the leafhoppers (Del-Claro e Oliveira, 1999; Fischer et al., 2005; Styrsky e Eubanks, 2007; Paris e Espadaler, 2009).

T. vulgaris is a pioneer tree, with fast growth, well-know to form forests quickly, shadowing the climax species. In areas that $P$. phalaenoides affect the $T$. vulgaris fitness, the ecologic succession may be changed, depending of the level of infestation (Oliveira e Frizzas, 2015). Furthermore, it's not very known the dynamics of the relationship between $P$. phalaenoides and native species.

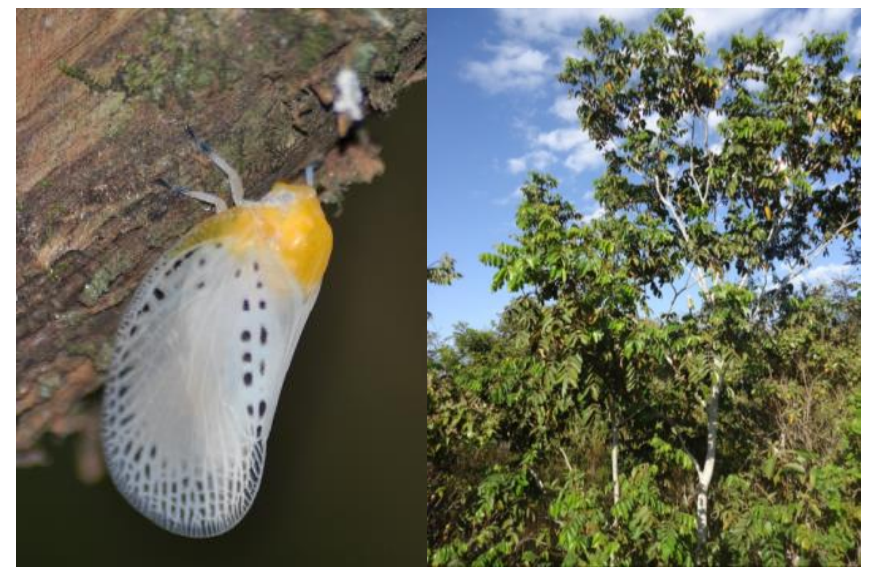

Figure 1. Poekilloptera phalaenoides L. on the branch of Tachigali vulgaris Silva \& Lima (left) and the whole plant (right; Foto: Carlos de Melo e Silva Neto).

In the study area, the most commons agricultural species are soybean (Glycine max L.; Fabaceae), corn (Zeamays L.; Poaceae), sorghum (Sorghum bicolor L.; Poaceae), sunflower (Helianthus annuus L.; Asteraceae), sugar cane (Saccharum spp.; Poaceae) and a few plantations of Eucaliptus sp. The disequilibrium of native vegetation around cultivated vegetation may increase the population of leafhoppers in native trees. At south-west of Goiás, an important agricultural region of Brazil, a little bit is known about the negative effects of this leafhopper in farms, but we call the attention the action of the negative interaction of $P$. phalaenoides with native forests (Gonçalves et al., 2016). Future studies should be carried out to confirm the relation to the increase of the population of the leafhopper and the reduction of the population of $T$. vulgaris, in addition to the possibility that the insect is also affecting other species.

\section{References}

Barroso, G.M.; Peixoto, A.L.; Costa, C.G.; Ichaso, C.L.F; Guimarães, E.F, Lima, H.C. 1991. Sistemática de Angiospermas do Brasil, ed. Viçosa, Minas Gerais, 309p.

Baptista, M.D.S. 2006. Taxonomia de Fulgoroidea no Brasil (Insecta: Hemiptera: Auchenorrhyncha), com ênfase em Dictyopharidae. Doutorado em Entomologia. Universidade Federal de Viçosa, UFV, Brasil. 2006.

Del-Claro, K.; Oliveira, P.S. 1999. Ant-Homoptera Interactions in a Neotropical Savanna: The Honeydew-Producing Treehopper, Guayaquila xiphias (Membracidae), and its Associated Ant Fauna on Didymopanax vinosum (Araliaceae). Biotropica, 31(1): 135-144.

Fischer, M.K.; Völkl, W.; Hoffmann, K.H. 2005. Honeydew production and honeydew sugar composition of polyphagous black bean aphid, Aphis fabae (Hemiptera: Aphididae) on various host plants and implications for ant-attendance. European Journal of Entomology, 102: 155-160.

Fujihara, R.T.; Forti, L.C.; Almeida, M.C.; Baldin, E.L. Insetos de importância econômica: guia ilustrado para identificação de famílias. Botucatu: F EPAP. 391 p. 2011.

Guimarães De Menezes, C.W.; Soares, M.A.; Assis Júnior, S.L., Fonseca, A.J. 2012. First Record of Poekilloptera phalaenoides (Hemiptera: Flatidae) Hosting Mimosa caesalpiniaefolia (Mimosaceae) in Diamantina, Minas Gerais State, Brazil. Forest Research 1:102.

Gonçalves, R.A. Souza, W.D.S.; Melo, A.P.C.; Silva-Neto, C.M.; Coolier, L.S.; Leandro, W.M. 2016. First record of Tingis americana Drak, 1992 (Tingidae) in Handroanthus heptaphyllus (Vell.) Mattos (Bignoniaceae) seedlings in a greenhouse in state of Goiás. Tree Dimensional, 1: 56-60. 
Querino, R.B.; Tonini, H.; Marsáro Júnior, A.L; Couceiro, S.R.M. 2007. O manejo de Acacia mangium Willd (Fabaceae) tem efeito na infestação da cigarrinha Poekilloptera phalaenoides L. (Hemiptera: Flatidae)? Boletim de Pesquisa e Desenvolvimento 04. Embrapa. 15 p.

Maes, J.M. 2004. Insectos asociados a algunos cultivos tropicales en el Atlántico de Nicaragua. Revista Nicaraguense de Entomologia, 64: (1): $1-134$.

Melo, A.; Fernandes, P.; Silva-Neto, C. 2016. Bed bugs associated with organic farming uchuva in Goiás (Brazil). Planet Science, 1: 21-25.

Oliveira, C.M.D.; Frizzas, M.R. 2015. Bio-ecology of Poekilloptera phalaenoides (Hemiptera: Flatidae) Under the Influence of Climatic Factors in the Brazilian Cerrado. Annals of the Entomological Society of America, 108(3), 263-271.

Paris, C.I.; Espadaler, X. 2009. Honeydew collection by the invasive garden ant Lasius neglectus versus the native ant $L$. grandis. Arthropod-Plant Interactions 3:75-85.

Silva-Neto, C.M.; Franceschinelli, E.V.; Bergamini, L.; Elias, M.A.S.; Morais, J.M.; Moreira, G.L.; Bergamini, B. 2016. High species richness of native pollinators in Brazilian tomato crops. Brazilian Journal of Biology, 77(3), epub.

Styrsky, J.D; Eubanks, M.D. 2007. Ecological consequences of interactions between ants and honeydew-producing insects. Proceedings of the Royal Society Biological Science. 274, 151-164. 